\title{
Correction to: In vitro prediction of stop- codon suppression by intravenous gentamicin in patients with cystic fibrosis: a pilot study
}

I. Sermet-Gaudelus*, M. Renouil, A. Fajac, L. Bidou, B. Parbaille, S. Pierrot, N. Davy, E. Bismuth, P. Reinert, G. Lenoir, J. F. Lesure, J. P. Rousset and A. Edelman

\section{Correction}

The original article [1] contains errors in Table 1 affecting some of the presented oligonucleotide sequences and readthrough values in Table 1 .

The corrected Table 1 displayed below shows the correct presentation of the affected oligonucleotide sequences for mutations Y122X, W128X, and G542X, as well as the correct readthrough values in columns ' 0 ' and ' 600 ' for the Y122X mutation. These corrections also extend to the corresponding data mentioned in the first paragraph of the Results section and Supplemental Table 1. Whatever the mutation, gentamicin induced readthrough remained very moderate which explains the absence of changes in patients harboring G542X, R1162X and W1282X mutation. This is in contrast to Y122X patients, who unexpectedly demonstrated restoration of adequate levels of functional protein in vivo inspite of low readthrough levels observed in vitro. One explanation could be a lower efficiency of the nonsense mediated mRNA (NMD) pathway in the cells of these patients, which can not be revealed with the dual reporter system.

Received: 16 July 2018 Accepted: 25 July 2018

Published online: 25 August 2018

\section{Reference}

1. Sermet-Gaudelus I, et al. In vitro prediction of stop-codon suppression by intravenous gentamicin in patients with cystic fibrosis: a pilot study. BMC
Table 1 Oligonucleotide sequences used in the dual reporter gene assay, corresponding to the Y122X, G542X, R1162X and W1292X mutations and the TQ in frame control. Readthrough level before and after incubation with $600 \mu \mathrm{g} / \mathrm{ml}$ gentamicin

\begin{tabular}{llll}
\hline Mutation & Oligonucleotide & 0 & 600 \\
\hline Y122X & w 5' TCTATCGCGATTTAACTAGGCATAGGC 3' & 0.02 & 0.12 \\
& C 5' GCCTATGCCTAGTTAAATCGCGATAGA 3' & & \\
W1282X & w 5'ACTTTGCAACAGTGAAGGAAAGCCTTT 3' & 0.115 & 0.35 \\
& C 5'AAAGGCTTTCCTTCACTGTTGCAAAGT 3' & & \\
R1162XX & w 5'CGATCTGTGAGCTGAGTCTTTAAGTTC 3' & 0.023 & 0.22 \\
& C 5'GAACTTAAAGACTCAGCTCACAGATCG 3' & & \\
G542X & w 5'AATATAGTTCTTTGAGAAGGTGGAATC 3' & 0.017 & 0.26 \\
& C 5'GATTCCACCTTCTCAAAGAACTATATT 3' & & \\
\hline
\end{tabular}

* Correspondence: isabelle.sermet@aphp.fr

Centre de Ressources et de Compétence en Mucoviscidose, Hôpital Necker-Enfants Malades, AP-HP, Paris, France
Med. 2007;5:5. https://doi.org/10.1186/1741-7015-5-5.
(- The Author(s). 2018 Open Access This article is distributed under the terms of the Creative Commons Attribution 4.0 International License (http://creativecommons.org/licenses/by/4.0/), which permits unrestricted use, distribution, and reproduction in any medium, provided you give appropriate credit to the original author(s) and the source, provide a link to the Creative Commons license, and indicate if changes were made. The Creative Commons Public Domain Dedication waiver (http://creativecommons.org/publicdomain/zero/1.0/) applies to the data made available in this article, unless otherwise stated. 